\title{
Microorganisms in Soils with High Nickel and Chromium Concentrations in Western Serbia
}

\author{
Olivera Stajković-Srbinović ${ }^{1 *}$, Dušica Delić ${ }^{1}$, Nataša Rasulić ${ }^{1}$, \\ Djordje Kuzmanović1, Beata Houšková ${ }^{2}$, \\ Biljana Sikirić1 ${ }^{1}$ Vesna Mrvić1 \\ ${ }^{1}$ Institute of Soil Science, Teodora Drajzera 7, 11000 Belgrade, Serbia \\ ${ }^{2}$ Soil Science and Conservation Research Institute, Bratislava, Slovak Republic
}

Received: 11 December 2016

Accepted: 18 January 2017

\begin{abstract}
The occurrence of microorganisms and their relationships with total and available heavy metal concentrations ( $\mathrm{Cu}, \mathrm{Zn}, \mathrm{Pb}, \mathrm{Cr}, \mathrm{Ni}, \mathrm{Cd}, \mathrm{Hg}$, and $\mathrm{As}$ ), as well as main soil chemical characteristics ( $\mathrm{pH}, \mathrm{P}$, $\mathrm{K}, \mathrm{Ca}, \mathrm{N}_{\text {tot }}, \mathrm{C}_{\text {org }}$ ) were evaluated in naturally metalliferous serpentine soils and non-serpentine soils with elevated $\mathrm{Ni}$ and $\mathrm{Cr}$ concentrations. Significant negative correlations were detected between ammonifiers $(r=-0.545, r=-0.371)$, oligonitrofiles $(r=-0.478, r=-0.458)$, total number of microorganisms $(r=-0.363$, $r=-0.393)$, and available $\mathrm{Ni}$ and $\mathrm{Cr}$. The number of actynomicetes and Azotobacter spp. was not affected by heavy metal concentrations, nor any other soil chemical characteristic. Ammonifiers correlated positively with $\mathrm{P}$ and $\mathrm{K}$ soil content, but negatively with soil $\mathrm{C}_{\text {org }}$. High positive correlations were obtained for available metal concentrations and soil $\mathrm{C}_{\text {org }}$ and $\mathrm{N}_{\text {tot }}$, while soil $\mathrm{pH}$ only correlated with available $\mathrm{Cr}$ and As. Stepwise multiple regression analyses indicated that increased $\mathrm{Ni}$ and $\mathrm{Cr}$ concentrations had overall little influence on microbial groups, and only ammonifiers were significantly affected by increased available $\mathrm{Ni}$, but $\mathrm{P}$ content had an even higher effect on their number in soil.
\end{abstract}

Keywords: heavy metals, microbial community, soil quality, serpentine, ammonifiers

\section{Introduction}

Microorganisms play an intrinsic role in soil formation and maintain fertility, structure, and stability of soils. They are vital to many of the ecological processes that sustain life, such as nutrient cycling, decay of plant matter, consumption and production of trace gases, and

*e-mail: oliverastajkovic@yahoo.com transformation of metals [1]. On the other hand, chemical and physical properties of soils, like quality and amount of soil organic matter, $\mathrm{pH}$, metal concentrations, etc., have a pronounced influence on the dynamics of the microbial community structure and function in soils [2].

Elevated heavy metal concentrations in soil may pose risks and hazards to humans and the ecosystem [3]. Microorganisms are the first group that undergoes any direct or indirect effects of heavy metals in the soil environment [4], and they are good indicators of changes 
in soil biological activity and soil health/quality. Heavy metal toxicity toward soil microorganisms has often been reported, but due to the wide variation in toxicity thresholds ( $>1000$-fold) among studies, the derivation of critical metal concentrations in soils for microbial groups/ processes is difficult [5-6]. Soil properties that affect both the toxicity of the metals and soil microbial populations may explain some of these variations. Negative effects of metal contamination on soil respiration, microbial biomass, enzyme activities, and microbial community size and diversity have been documented [7-11]. However, the results indicating no differences between polluted and unpolluted sites in terms of biomass, enzymatic activity, or abundance of some groups of microorganisms have also been published [4, 12-13]. The estimated differences could be caused by limited bioavailability of heavy metals and/or resistance developed by the microbial community to chronic high heavy metal concentrations [13], but also by other physical and chemical interactions in the soil, indicating the complexity of heavy metal influence in the ecosystem. Therefore, the influence of heavy metals and other soil properties on soil microorganisms in field conditions should be analyzed.

Some soils in western Serbia, serpentine soils, are characterized by high levels of heavy metals, mainly $\mathrm{Ni}$ and $\mathrm{Cr}$, since they are formed on ultramafic rocks or sediments originating from the ultramafic rocks [14]. In addition, non-serpentine soils with elevated $\mathrm{Ni}$ and $\mathrm{Cr}$ concentrations are also present in this part of the country. These elevated metal concentrations are probably caused by natural erosion and accumulation of weathering products of ultramafic rocks, but anthropogenic influence cannot be excluded. Our study aimed to evaluate the relationships between the occurrence of some groups of microorganisms and total and available heavy metals, as well as other chemical characteristics of soils in naturally metalliferous serpentine and nonserpentine soils with a wide gradient of elevated $\mathrm{Ni}$ and Cr concentrations.

\section{Material and Methods}

\section{Site Description}

The soils were collected from two regions in western Serbia: Maljen Mountain, which is of ultramafic, serpentine origin (naturally high in $\mathrm{Ni}, 10$ samples); and non-serpentine soils surrounding the town of Čačak (with elevated levels of Ni, 23 samples) (Table 1). On Maljen, Leptosols formed on serpentinized harzburgite and Jurassic serpentines dominate, mainly under forests and grass vegetation to a lower extent (Table 2). In the Čačak area Vertisol and Fluvisol soils are dominant, formed on Neogene and alluvial sediments (non-serpentine soils), and arable land and orchards dominate (Table 2). The samples were collected in autumn 2009, from a depth of $25 \mathrm{~cm}$ and used for chemical and microbiological analyses.

\section{Soil Microbiological Analysis}

The plate count method was used to enumerate the total number of microorganisms, the number of fungi, actinomycetes, and ologonitrophiles in soil samples. The number of microorganisms was determined on the agarised soil extract, fungi on the Chapek medium [15], actinomycetes on the synthetic agar with sacharose according to Krasiljnikoy [16], and oligonitrophiles on the medium according to Fyodorov [16]. The ammonifiers and Azotobacter spp. were estimated by the most probable number (MPN) in medium with asparagines as the source of nitrogen for ammonifiers, while liquid medium with mannitol was used for Azotobacter spp. [17].

\section{Soil Chemical Analysis}

Soil $\mathrm{pH}$ was determined with a glass electrode $\mathrm{pH}$ meter in $1 \mathrm{~N} \mathrm{KCl} \mathrm{(in} \mathrm{ratio} \mathrm{soil:} \mathrm{KCl} 1: 2.5$ ). Available $\mathrm{P}$ and $\mathrm{K}$ in soil were determined by the AL-method of EgnerRiehm, while $\mathrm{CaCO}_{3}$ was determined volumetrically using a Sheibler calcimeter. Soil organic $\mathrm{C}\left(\mathrm{C}_{\mathrm{org}}\right)$ and total $\mathrm{N}\left(\mathrm{N}_{\text {tot }}\right)$ were determined with an elemental CNS analyser, Vario model EL III (Hanau, Germany). The total content of heavy metals $(\mathrm{Cd}, \mathrm{Cr}, \mathrm{Cu}, \mathrm{Hg}, \mathrm{As}, \mathrm{Ni}, \mathrm{Pb}$, and $\mathrm{Zn}$ ) was determined by acid digestion $\left(\mathrm{HNO}_{3}\right)$ and by plasma emission spectrometry ICAP 6300 ICP (Cambridge, UK). Available forms of $\mathrm{Cd}, \mathrm{Cr}, \mathrm{Cu}, \mathrm{As}, \mathrm{Ni}, \mathrm{Pb}$, and $\mathrm{Zn}$ in soils were extracted by DTPA [18] and determined by ICAP 6300 ICP.

\section{Statistics}

Statistical differences on microbial parameters between sites were evaluated using one-way ANOVA. Pearson's correlation and stepwise multiple linear regression were performed to determine the relationship between the number of microorganisms and soil characteristics. The SPSS 16.0 software package was used.

\section{Results}

\section{Soil Properties and Heavy Metal Concentrations}

Chemical characteristics and heavy metal concentrations of soils in two investigated areas are presented in Table 1. In both investigated areas, in 32 of 33 soil samples investigated, total $\mathrm{Ni}$ concentrations were above maximum allowed values for agricultural soils according to national legislation (MAC) (Tables 1-2). Concentrations of $\mathrm{Cr}$ above MAC were detected in all serpentine and eight samples from the non-serpentine area. There was a wide gradient of total $\mathrm{Ni}$ concentrations in soils from 47 to $1,689 \mathrm{mg} \mathrm{kg}^{-1}$, as well as $\mathrm{Cr}$ from 47 to $957 \mathrm{mg} \mathrm{kg}^{-1}$ (Table 2). Although elevated concentrations were detected in both areas, two areas significantly differ in total and available $\mathrm{Ni}$ and $\mathrm{Cr}$ concentrations. Moreover, 
the average total and available $\mathrm{Ni}$ concentrations were about 9 and 20 times greater in serpentine compared to non-serpentine soils. The concentrations of all the other heavy metals evaluated $(\mathrm{Cu}, \mathrm{Zn}, \mathrm{Pb}, \mathrm{Cd}$, As (metalloid), and $\mathrm{Hg}$ ) were below MAC in both areas, with exceptions of single metals in two soil samples (Tables 1-2). Concentrations of total $\mathrm{Pb}$ were significantly higher in serpentine soil, while available $\mathrm{Cd}$ and total $\mathrm{Cu}$ and $\mathrm{Hg}$ concentrations, as well as both forms of As were significantly higher in non-serpentine soil. There were no significant differences between soil $\mathrm{pH}$ in two areas, which was mostly weak acid reaction. Contents of $\mathrm{P}$ and $\mathrm{K}$ were significantly higher in non-serpentine, while $\mathrm{N}_{\text {tot }}$ and $\mathrm{C}_{\text {org }}$ were significantly higher in serpentine soils. The $\mathrm{C} / \mathrm{N}$ ratio was favorable in almost all soil samples. The obtained chemical characteristics correspond to typical serpentine soil under the forests $[12,19]$.

\section{Microbiological Characteristics of Soils}

In our research, the number of fungi, actinomycetes, and Azotobacter spp. did not significantly differ between the areas, while the total number of microorganisms, ammonifier, and oligonitrofiles were significantly lower in serpentine soil (Table 2). The total microbial number was in the range of 3.67-38.33 x $10^{6}$ and 2.33-61.33 x $10^{6} \mathrm{CFU} \mathrm{g}^{-1}$ of soil in serpentine and non-serpentine soil, respectively. Although there were no significant differences between Azotobacter spp. in two areas, their number in serpentine soil was very low (0-4 MPN g-1 of soil) in respect to nonserpentine soil (0-1100 MPN g $\mathrm{g}^{-1}$ of soil). The number of ammonifiers was in the range of $0.70-110 \times 10^{5}$ and 7.5-140 × $10^{5} \mathrm{MPN} \mathrm{g}^{-1}$ of soil, while oligonitrofiles ranged $10-82.67 \times 10^{5}$ and $5-191 \times 10^{5} \mathrm{CFU} \mathrm{g}^{-1}$ of soil for serpentine and non-serpentine soil, respectively.

Table 1 . Soil chemical properties and heavy metal concentrations.

\begin{tabular}{|c|c|c|c|c|c|c|c|c|}
\hline & \multicolumn{3}{|c|}{ Serpentine soil } & \multicolumn{3}{|c|}{ Non-serpentine soil } & & \\
\hline \multicolumn{9}{|c|}{ Chemical properties of soil } \\
\hline & Min & Max & Mean \pm SD & Min & Max & Mean \pm SD & ANOVA & MAC \\
\hline $\mathrm{pH}_{(\mathrm{KCl})}$ & 5.32 & 5.82 & $5.61 \pm 0.18$ & 3.50 & 7.01 & $5.80 \pm 1.01$ & ns & \\
\hline $\mathrm{P}_{2} \mathrm{O}_{5}\left[\mathrm{mg} 100 \mathrm{~g}^{-1}\right]$ & 0.10 & 0.78 & $0.26 \pm 0.23$ & 0.00 & 58.43 & $14.25 \pm 14.98$ & $* *$ & \\
\hline $\mathrm{K}_{2} \mathrm{O}\left[\mathrm{mg} 100 \mathrm{~g}^{-1}\right]$ & 9.82 & 21.08 & $14.93 \pm 3.94$ & 13.41 & 45.00 & $27.82 \pm 11.46$ & $* *$ & \\
\hline $\mathrm{CaCO}_{3}\left[\mathrm{mg} \mathrm{kg}^{-1}\right]$ & 0 & 0 & 0 & 0 & 8.48 & $0.852 \pm 1.77$ & ns & \\
\hline $\mathrm{N}_{\text {tot }}[\%]$ & 0.37 & 0.88 & $0.47 \pm 0.19$ & 0.11 & 0.44 & $0.23 \pm 0.09$ & $* * *$ & \\
\hline $\mathrm{C}_{\mathrm{org}}[\%]$ & 2.17 & 11.39 & $6.21 \pm 2.36$ & 0.94 & 4.46 & $2.38 \pm 1.02$ & $* * *$ & \\
\hline \multicolumn{9}{|c|}{ Total heavy metal concentrations $\left(\mathrm{mg} \mathrm{kg}^{-1}\right)$} \\
\hline $\mathrm{Cu}$ & 6 & 11 & $10.1 \pm 2.33$ & 16 & 181 & $36.13 \pm 34.13$ & * & 100 \\
\hline $\mathrm{Zn}$ & 40 & 119 & $67.1 \pm 21.84$ & 44 & 123 & $63.91 \pm 16.10$ & ns & 300 \\
\hline $\mathrm{Pb}$ & 26 & 94 & $45 \pm 19.81$ & 11 & 100 & $30.04 \pm 17.99$ & * & 100 \\
\hline $\mathrm{Cr}$ & 359 & 957 & $591.4 \pm 159.83$ & 47 & 164 & $84.91 \pm 35.40$ & $* * *$ & 100 \\
\hline $\mathrm{Ni}$ & 770 & 1689 & $1166.1 \pm 253.87$ & 47 & 329 & $132.0 \pm 80.03$ & $* * *$ & 50 \\
\hline $\mathrm{Cd}$ & 0.2 & 0.85 & $0.29 \pm 0.20$ & 0.2 & 0.85 & $0.32 \pm 0.15$ & ns & 3 \\
\hline As & 1 & 20 & $6.3 \pm 5.88$ & 10 & 33 & $15.13 \pm 5.76$ & $* * *$ & 25 \\
\hline $\mathrm{Hg}$ & 0.007 & 0.031 & $0.0174 \pm 0.0078$ & 0.020 & 0.282 & $0.0647 \pm 0.0542$ & $*$ & 2 \\
\hline \multicolumn{9}{|c|}{ Available heavy metal concentrations $\left(\mathrm{mg} \mathrm{kg}^{-1}\right)$} \\
\hline $\mathrm{Cu}$ & 0.7 & 1.9 & $1.07 \pm 0.34$ & 0.8 & 35.4 & $4.61 \pm 7.17$ & ns & \\
\hline $\mathrm{Zn}$ & 0.6 & 26.6 & $5.54 \pm 7.48$ & 0.4 & 9.1 & $2.36 \pm 2.08$ & ns & \\
\hline $\mathrm{Pb}$ & 0.5 & 18.8 & $5.37 \pm 5.09$ & 0.7 & 19.9 & $3.46 \pm 3.83$ & ns & \\
\hline $\mathrm{Cr}$ & 0.012 & 0.048 & $0.0259 \pm 0.0083$ & $\mathbf{0}$ & 0.014 & $0.0059 \pm 0.0016$ & $* * *$ & \\
\hline $\mathrm{Ni}$ & 69 & 186 & $118.2 \pm 38.19$ & 1.00 & 29.30 & $6.60 \pm 6.93$ & $* * *$ & \\
\hline $\mathrm{Cd}$ & 0.04 & 0.80 & $0.21 \pm 0.21$ & 0.03 & 0.13 & $0.10 \pm 0.09$ & $*$ & \\
\hline As & 0.02 & 0.19 & $0.07 \pm 0.04$ & 0.01 & 0.47 & $0.16 \pm 0.12$ & $*$ & \\
\hline
\end{tabular}

MAC - maximum allowed concentrations for total heavy metals in agricultural soils, serpentine soil $(\mathrm{n}=10)$, non-serpentine soil $(\mathrm{n}=23)$, ns-non significant differences between soils, $* \mathrm{P}<0.05, * * \mathrm{P}<0.01, * * * \mathrm{P}<0.001$ 
Table 2. Microbiological properties of investigated soils and $\mathrm{Ni}$ and $\mathrm{Cr}$ total concentrations $\left(\mathrm{mg} \mathrm{kg}^{-1}\right)$.

\begin{tabular}{|c|c|c|c|c|c|c|c|c|}
\hline Land use & $\mathrm{Cr}$ & $\mathrm{Ni}$ & $\begin{array}{l}\text { Total number of } \\
\text { microorganisms } \\
\quad \times 10^{6} \mathrm{CFU}\end{array}$ & $\begin{array}{c}\text { Fungi } \\
\times 10^{4} \mathrm{CFU}\end{array}$ & $\begin{array}{c}\text { Actinomycetes } \\
\times 10^{4} \mathrm{CFU}\end{array}$ & $\begin{array}{c}\text { Azotobacter } \\
\text { MPN }\end{array}$ & $\begin{array}{l}\text { Ammonifiers } \\
\text { x } 10^{5} \mathrm{MPN}\end{array}$ & $\begin{array}{c}\text { Oligonitrofiles } \\
\times 10^{5} \mathrm{CFU}\end{array}$ \\
\hline \multicolumn{9}{|c|}{ Serpentine soil } \\
\hline Forest & 607 & 1689 & 12.67 & 6.33 & 0.33 & 0 & 0.90 & 49.33 \\
\hline Forest & 957 & 1418 & 15.33 & 11.00 & 16.33 & 0 & 3.00 & 65.67 \\
\hline Forest & 694 & 1260 & 14.00 & 10.33 & 1.67 & 4 & 110 & 44.33 \\
\hline Forest & 653 & 1248 & 13.00 & 10.67 & 2.33 & 0 & 1.10 & 53.00 \\
\hline Forest & 359 & 1091 & 21.67 & 20.67 & 32.67 & 4 & 1.10 & 82.67 \\
\hline Forest & 514 & 1069 & 16.33 & 8.00 & 8.00 & 0 & 45 & 46.00 \\
\hline Meadow & 601 & 1079 & 16.00 & 6.67 & 4.67 & 0 & 15 & 46.00 \\
\hline Forest & 524 & 1045 & 6.00 & 13.33 & 9.67 & 0 & 0.90 & 61.33 \\
\hline Meadow & 522 & 992 & 3.67 & 17.33 & 3.00 & 4 & 0.70 & 10.00 \\
\hline Meadow & 485 & 770 & 38.33 & 24.00 & 7.00 & 4 & 9.50 & 48.33 \\
\hline Mean \pm SD & & & $15.7 \pm 9.46$ & $12.83 \pm 6.00$ & $8.56 \pm 9.69$ & $1.60 \pm 2.06$ & $18.72 \pm 34.87$ & $50.66 \pm 18.59$ \\
\hline \multicolumn{9}{|c|}{ Non-serpentine soil } \\
\hline Orchard & 164 & 329 & 41.00 & 14.00 & 1.67 & 450 & 140 & 46.67 \\
\hline${ }^{12}$ Meadow & 177 & 294 & 11.33 & 17.00 & 6.33 & 95 & 45 & 69.00 \\
\hline Arable & 130 & 248 & 13.67 & 9.00 & 6.00 & 45 & 110 & 92.67 \\
\hline Meadow & 110 & 210 & 28.00 & 9.00 & 7.33 & 150 & 140 & 67.00 \\
\hline Arable & 106 & 195 & 13.67 & 7.00 & 2.00 & 45 & 15 & 95.00 \\
\hline Orchard & 121 & 185 & 35.67 & 21.33 & 2.00 & 150 & 20 & 111.00 \\
\hline Meadow & 102 & 165 & 61.33 & 21.33 & 12.00 & 450 & 110 & 191.00 \\
\hline Arable & 73 & 158 & 19.33 & 17.00 & 5.67 & 9 & 25 & 111.67 \\
\hline Arable & 66 & 146 & 22.67 & 6.33 & 12.00 & 95 & 20 & 118.00 \\
\hline${ }^{20}$ Orchard & 85 & 127 & 19.67 & 6.33 & 7.67 & 0 & 140 & 48.00 \\
\hline Arable & 84 & 122 & 20.00 & 15.67 & 5.00 & 1100 & 45 & 67.00 \\
\hline Yard & 73 & 118 & 31.33 & 24.00 & 7.33 & 25 & 45 & 102.00 \\
\hline Meadow & 79 & 92 & 14.33 & 20.33 & 2.33 & 45 & 45 & 89.67 \\
\hline Yard & 57 & 83 & 25.00 & 20.00 & 2.33 & 95 & 140 & 102.67 \\
\hline Orchard & 71 & 79 & 28.33 & 15.33 & 2.33 & 95 & 140 & 102.67 \\
\hline Yard & 57 & 74 & 26.67 & 18.00 & 5.00 & 95 & 140 & 81.67 \\
\hline Meadow & 57 & 72 & 36.33 & 25.00 & 3.33 & 25 & 110 & 83.67 \\
\hline Orchard & 56 & 64 & 32.67 & 13.67 & 0.67 & 150 & 140 & 97.33 \\
\hline Meadow & 66 & 62 & 25.00 & 7.67 & 1.00 & 25 & 45 & 73.33 \\
\hline Arable & 60 & 60 & 14.33 & 36.00 & 2.33 & 25 & 7.50 & 38.33 \\
\hline Orchard & 54 & 59 & 26.00 & 23.33 & 2.33 & 95 & 2 & 89.00 \\
\hline Meadow & 58 & 53 & 22.33 & 19.33 & 10.33 & 45 & 140 & 91.67 \\
\hline Forest & 47 & 47 & 2.33 & 9.67 & 3.00 & 0 & 30 & 5.00 \\
\hline Mean \pm SD & & & $24.82 \pm 12.10$ & $16.21 \pm 7.35$ & $4.78 \pm 3.89$ & $143.86 \pm 240.38$ & $78.80 \pm 53.86$ & $85.83 \pm 35.33$ \\
\hline ANOVA & & & $*$ & ns & ns & $\mathrm{ns}$ & $* *$ & $* *$ \\
\hline
\end{tabular}

$\mathrm{CFU} \mathrm{g}^{-1}$ soil or MPN g${ }^{-1}$ soil; ns-non significant differences between soils, ${ }^{*} \mathrm{P}<0.05$, $* * \mathrm{P}<0.01$, Soil no $12 \mathrm{As}=33$ and $\mathrm{Pb}=100 \mathrm{mg} \mathrm{kg}^{-1}$, Soil no $20 \mathrm{Cu}=181 \mathrm{mg} \mathrm{kg}^{-1}$ 
Table 3. Significant Pearson's correlation coefficients between groups of microorganisms and chemical characteristics of soils.

\begin{tabular}{|c|c|c|c|c|c|c|c|c|c|c|c|c|}
\hline & $\mathrm{pH}$ & $\mathrm{P}_{2} \mathrm{O}_{5}$ & $\mathrm{~K}_{2} \mathrm{O}$ & $\mathrm{CaCO}_{3}$ & $\mathrm{~N}_{\text {tot }}$ & $\mathrm{C}_{\text {org }}$ & TMic & Fun & Act & Azo & $\mathrm{Amm}$ & Olig \\
\hline $\mathrm{P}_{2} \mathrm{O}_{5}$ & $0.499^{* *}$ & 1 & & & & & & & & & & \\
\hline $\mathrm{K}_{2} \mathrm{O}$ & & $0.548^{* *}$ & 1 & & & & & & & & & \\
\hline $\mathrm{CaCO}_{3}$ & & & & 1 & & & & & & & & \\
\hline $\mathrm{N}_{\text {tot }}$ & & & & & 1 & & & & & & & \\
\hline $\mathrm{C}_{\text {org }}$ & & $-0.375^{*}$ & & & $0.961^{* *}$ & 1 & & & & & & \\
\hline TMic & & & $0.414^{*}$ & & & & 1 & & & & & \\
\hline Fun & & & $0.370^{*}$ & & & & $0.348^{*}$ & 1 & & & & \\
\hline Act & & & & & & & & & 1 & & & \\
\hline Azo & & & & & & & $0.353^{*}$ & & & 1 & & \\
\hline $\mathrm{Amm}$ & & $0.554^{* *}$ & $0.377^{*}$ & & $-0.356^{*}$ & $-0.424^{*}$ & $0.447^{*}$ & & & & 1 & \\
\hline Olig & & & & & & & $0.654^{* *}$ & & & & & 1 \\
\hline \multicolumn{13}{|c|}{ Total metal concentrations } \\
\hline $\mathrm{Cu}$ & & & $0.357^{*}$ & $0.890^{* *}$ & & & & & & & & \\
\hline $\mathrm{Zn}$ & & & & & $0.487^{* *}$ & $0.426^{* *}$ & & & & & & \\
\hline $\mathrm{Pb}$ & & & & & $0.584^{* *}$ & $0.565^{* *}$ & & & & & & \\
\hline $\mathrm{Cr}$ & & $-0.409^{*}$ & $-0.487^{* * *}$ & & $0.570^{* *}$ & $0.653^{* *}$ & $-0.351^{*}$ & & & & $-0.449^{*}$ & $-0.437^{* *}$ \\
\hline $\mathrm{Ni}$ & & $-0.410^{*}$ & $-0.506^{* *}$ & & $0.532^{* *}$ & $0.654^{* *}$ & $-0.369^{*}$ & & & & $-0.474^{*}$ & $-0.427^{* *}$ \\
\hline $\mathrm{Cd}$ & & & & & $0.389^{*}$ & & & & & & & \\
\hline As & & $0.362^{*}$ & $0.464^{* *}$ & & & & & & & & & \\
\hline $\mathrm{Hg}$ & & & $0.364^{*}$ & & & & $0.477^{* *}$ & & & & & $0.643^{* *}$ \\
\hline \multicolumn{13}{|c|}{ Available metal concentrations } \\
\hline $\mathrm{Cu}$ & & & $0.391^{*}$ & $0.895^{* *}$ & & & & & & & & \\
\hline $\mathrm{Zn}$ & & & & & $0.730^{* *}$ & $0.717^{* *}$ & & & & & & \\
\hline $\mathrm{Pb}$ & & & & & $0.578^{* *}$ & $0.532^{* *}$ & & & & & & \\
\hline $\mathrm{Cr}$ & $-0.367^{*}$ & $-0.393^{*}$ & $-0.439^{*}$ & & $0.619^{* *}$ & $0.666^{* *}$ & $-0.393^{*}$ & & & & $-0.371^{*}$ & $-0.458^{* *}$ \\
\hline $\mathrm{Ni}$ & & $-0.433^{*}$ & $-0.498^{* *}$ & & $0.734^{* *}$ & $0.813^{* *}$ & $-0.363^{*}$ & & & & $-0.545^{* *}$ & $-0.478^{* *}$ \\
\hline $\mathrm{Cd}$ & & & & & $0.724^{* *}$ & $0.699^{* *}$ & & & & & & \\
\hline As & $-0.610^{*}$ & & $0.416^{*}$ & & & & & $0.537^{*}$ & & & & \\
\hline
\end{tabular}

TMic- Total microorganisms, Fun- Fungi, Act- Actinomycetes, Azo- Azotobacter, Amm- Ammonifiers, Olig- Oligonitrofiles, No of soil samples analyzed $\mathrm{n}=33, *_{-} \mathrm{P}<0.05$, **- $\mathrm{P}<0.01$

Although moderate, significant negative correlations were detected between total As well as available $\mathrm{Ni}$ and $\mathrm{Cr}$ concentrations and total microorganisms number, ammonifiers, and oligonitrofiles (Table 3). The numbers of actynomicetes and Azotobacter spp. were not affected by heavy metal concentrations, nor any other heavy metal or soil chemical characteristic investigated. Positive correlations between $\mathrm{Hg}$ and total number of microorganisms as well as oligonitrofiles were observed, while available As positively correlated with the number of fungi. The concentrations of these metals were far below MAC.
In our study, there was no correlation between $\mathrm{pH}$ and any microbiological group investigated. Significant negative correlations were detected only between $\mathrm{pH}$ and available $\mathrm{Cr}$ and As. Ammonifiers positively correlated to $\mathrm{P}$ and $\mathrm{K}$, but negatively correlated with soil $\mathrm{C}_{\text {org }}$ and $\mathrm{N}_{\text {tot }}$, while the number of microorganisms and fungi were in positive correlation with $\mathrm{K}$. Considering other interactions, there were significant correlations between total and available forms of each investigated metal (Table 3). $\mathrm{N}_{\text {tot }}$ and $\mathrm{C}_{\text {org }}$ were in significant positive correlation with total and/or available concentrations of $\mathrm{Zn}, \mathrm{Pb}, \mathrm{Cr}$, $\mathrm{Ni}$, and $\mathrm{Cd}$. Negative correlations were noticed between 
Table 4. Stepwise multiple regression of microbial groups (dependent variables) and soil properties (predictors) $(\mathrm{P}<0.05)$.

\begin{tabular}{|c|c|c|}
\hline Dependent variable & Predictor & $\mathrm{R}^{2}$ \\
\hline Ammonifiers & $\mathrm{P}_{2} \mathrm{O}_{5}$ & 0.307 \\
\hline & $\mathrm{P}_{2} \mathrm{O}_{5}, \mathbf{N i}^{\mathrm{a}}$ & 0.421 \\
\hline Total microorganisms & $\mathrm{Hg}^{\mathrm{t}}$ & 0.227 \\
\hline Oligonitrofiles & $\mathrm{Hg}^{\mathrm{t}}$ & 0.413 \\
\hline & $\mathrm{Hg}^{\mathrm{t}}, \mathbf{P b}$ & 0.525 \\
\hline & $\mathrm{Hg}^{\mathrm{t}}, \mathbf{P b} \mathbf{P}^{\mathrm{t}}, \mathbf{C a C O}$ & 0.596 \\
\hline & $\mathrm{Hg}^{\mathrm{t}}, \mathbf{P b}^{\mathrm{t}}, \mathbf{C a C O}_{3}, \mathrm{Zn}^{\mathrm{t}}$ & 0.654 \\
\hline Fungi & $\mathrm{As}^{\mathrm{a}}$ & 0.288 \\
& $\mathrm{As}^{\mathrm{a}}, \mathbf{C d}^{\mathrm{t}}$ & 0.389 \\
\hline
\end{tabular}

a - available, $t$ - total metal concentrations, $\mathrm{R}^{2}$ - square of the coefficient of multiple correlation which indicates the proportion of the variance in the dependent variable that is predictable from the independent variable (predictor), negative influence of predictor is marked in bold

$\mathrm{P}$ and $\mathrm{K}$ content, and $\mathrm{Ni}$ and $\mathrm{Cr}$, while $\mathrm{Cu}$ and $\mathrm{As}$ correlated positively with $\mathrm{K}$.

Stepwise linear regression analysis is a statistical technique used to investigate and model the relationships between variables from multi-factor data. In our study, stepwise multiple regression analysis was used to explore the relationship between all soil characteristics evaluated and the microbial groups, aiming to identify the factors with the highest influence. The analysis indicated that $\mathrm{P}$ and $\mathrm{Ni}$ are the most important factors that significantly account for variation in ammonifiers $(42 \%$ of variation explained), with the prevalence of $\mathrm{P}(30 \%)$ over $\mathrm{Ni}$ $(12 \%)$ (Table 4$)$. The total number of microorganisms was the most significantly affected by $\mathrm{Hg}(22 \%$ of variation explained), while the number of oligonitrofiles was affected with total $\mathrm{Hg}, \mathrm{Pb}, \mathrm{CaCO}_{3}$, and $\mathrm{Zn}(65 \%$ of variation explained).

\section{Discussion}

Although nickel is one of the essential trace metals for microorganisms, plants, and animals, constant exposure to excessive nickel in soils could strongly affect the inhabitant microorganisms, resulting in adverse effects on ecosystem functioning [20-22]. Chromium is not considered essential for microorganisms and plants, but it is a micronutrient in humans and can be highly toxic when accumulated [23]. The response of soil microorganisms to heavy metals depends on soil properties, heavy metal bioavailability, indigenous soil microbial properties, experimental conditions (laboratory or field study), and period of metal exposure (acute or chronic), etc. In our research, the effects of long-term exposure of soil microbial community to elevated $\mathrm{Ni}$ and $\mathrm{Cr}$ concentrations (values above MAC) were studied in serpentine and non-serpentine soils with a wide gradient of total $\mathrm{Ni}$ and $\mathrm{Cr}$ concentrations. Serpentine (ultramafic) soils due to naturally high concentrations of metals, particularly $\mathrm{Ni}$, $\mathrm{Cr}$, and $\mathrm{Co}$, and low concentrations of $\mathrm{Ca}, \mathrm{N}, \mathrm{P}$, and $\mathrm{K}$ represent a naturally stressed environment [24-25]. Lower microbial density and activity of serpentine areas in respect to non-serpentine outcrops have been reported previously [24]. In our study, despite the significant differences in $\mathrm{Ni}$ and $\mathrm{Cr}$ and some other heavy metal concentrations between the two areas, only some microbial groups were significantly affected. The number of fungi, actinomycetes, and Azotobacter spp. did not significantly differ between the areas, while the total number of microorganisms, ammonifier, and oligonitrofiles were significantly lower in serpentine soil. Generally the number of total microorganisms, oligonitrofiles, and actynomicetes in serpentine soil in our study, corresponded to data by Mandić et al. [26] in soils high in $\mathrm{Ni}$ and $\mathrm{Cr}$ and similar chemical characteristics. The lower number of bacteria in serpentines of Andaman was detected compared to our study, but the differences could be attributed to a much greater Ni content in soils of Andaman (1,740$8,033.4 \mathrm{mg} \mathrm{kg}^{-1}$ soil) [24]. The total culturable number of different microbial groups of the contaminated soils was decreased, but certain groups of soil microbes were particularly sensitive to long-term contamination, asymbiotic nitrogen-fixers, and heterotrophic bacteria, while actinomicetes and fungi were less affected [27], which corresponds to our results.

Negative effects of an increase of $\mathrm{Ni}$ biological availability in contaminated soils on metabolic activities and diversity of microbes have been observed [11, 2830]. However, microbiological activity is not necessarily inhibited by high available Ni concentrations as indicated in the research of Pessoa-Filho et al. [31], who found the differences in microbial biomass $\mathrm{C}$, and some enzymatic activity between two ultramafic soils with different high $\mathrm{Ni}$ concentrations but not with non-ultramafic soil with lower Ni. Some research indicates that the plate counts seem to be a more appropriate technique for detecting the effect of metals on soil bacteria than culture-independent methods [32].

Negative correlation between available $\mathrm{Ni}$ and ammonifiers as well as oligonitrofiles obtained in our study was previously reported [26]. Niemeyer et al. [10] reported a negative correlation between total $\mathrm{Ni}$ and $\mathrm{Cr}$ as well as other heavy metals (Fe, $\mathrm{Cu}, \mathrm{Mn}, \mathrm{Zn}, \mathrm{Cd}, \mathrm{Pb}$ ) and ammonifiers. Previous findings in experimental conditions indicate that asymbiotic $\mathrm{N}_{2}$ fixers are the most affected microbial group with an increasing concentration of $\mathrm{Ni}$ [33]. In addition, adding Ni to soil caused a $60 \%$ decrease in the number of oligotrophic bacteria and inhibits nitrification processes by up to $20 \%$ in comparison to clean soils [34]. It seems that the microorganisms included in the nitrogen metabolism in the soil (ammonifiers and oligonitrofiles) are among the more sensitive to the heavy metal pollution/concentrations [27, 33].

In agreement with our research, it has been reported that actinomycetes are less sensitive to $\mathrm{Ni}$ and other 
contamination [4, 26-27]. Long-term nickel pollution favored the prevalence of several dominant bacterial guilds, in particular Actinobacteria showed tolerance [21]. The tolerance ability of actinobacteria toward different stressful environmental factors, particularly heavy metals, was recognized and possibilities for its use in bioremediation were discussed [21, 35-36].

In the study, positive correlations of $\mathrm{Hg}$ and $\mathrm{As}$ and the total number of microorganisms, oligonitrofiles, and fungi were observed, but is should be pointed out that the concentrations of these metals were far below MAC. In some research low concentrations of some heavy metals in the soil may increase enzymatic activity, but they are irreversibly inhibited by high concentrations of these metals [37]. Some heavy metals increased the counts of oligotrophic and copiotrophic bacteria, actinomyces, fungi, and even ammonifying bacteria, but at the same time decreased the number of Azotobacter [38]. The growth of some microbial groups may be stimulated by heavy metals in soils of neutral reaction, but inhibited in acid soils demonstrated [39]. This data indicates that the effect of heavy metals should be interpreted in view of other environmental factors.

Microbial communities are influenced not only by heavy metals, but also by other environmental factors such as soil $\mathrm{pH}$, temperature, moisture, and organic matter quality, etc. [8]. The $\mathrm{pH}$ level was often connected with microbiological characteristics and availability of heavy metals in soil [21, 30, 40-42]. In our study, there was no correlation between $\mathrm{pH}$ and any microbiological group investigated, while significant negative correlations were detected only between $\mathrm{pH}$ and available $\mathrm{Cr}$ and $\mathrm{As}$, which is possibly due to the lack of significant variation in $\mathrm{pH}$ between samples. Previously, significant correlation between heavy metals and $\mathrm{pH}$ was not detected due to faintly acidic soil $[11,43-44]$. It is considered that decreasing soil $\mathrm{pH}$ is the main factor influencing increased nickel solubility, while clay content, iron- manganese mineral, and soil organic matter are of secondary importance [45].

Considering other interactions, there were significant correlations between total and available forms of each investigated metal (data not shown) [43, 46-47]. $\mathrm{N}_{\text {tot }}$ and $\mathrm{C}_{\text {org }}$ were in significant positive correlation with total and/or available concentrations of $\mathrm{Zn}, \mathrm{Pb}, \mathrm{Cr}, \mathrm{Ni}$, and $\mathrm{Cd}$. Deng et al. [11] reported significant correlations between several total heavy metals and soil organic contents, but a negative correlation with microbial activity and metals.

Stepwise multiple regression analysis was widely used to investigate and model the relationship between different soil parameters, but it has recently become more common in evaluation factors affecting soil microbial groups [48-50]. In our study, based on the analysis of all soil parameters investigated only ammonifiers were significantly affected by increased available $\mathrm{Ni}$, but $\mathrm{P}$ content had an even greater effect on their number in soil. Previous studies suggest that changes in soil microbiological functioning in serpentine soils were more related to the soil organic matter than to Ni concentrations $[12,31]$. The previous results also indicate that microbial diversity and community structure may be regulated by the availability of critical limiting resources $[12,51]$. In our research the $\mathrm{P}$ content in soil could be a limiting factor for a number of ammonifiers, since the $\mathrm{P}$ content in soils investigated is generally low.

Additionally, the microbial community may adapt to the heavy metal concentrations overcoming the negative effects of contamination [52-54]. None of the microbial parameters (biomass, respiration or respiratory quotient, or diversity) were correlated to the gradient in heavy metals of ultramafic soils, suggesting adaptation by the microbial community to the stress imposed by edaphic conditions [12]. Some studies showed microbial tolerance and adaptation to soil contamination due to the long-term metal exposure and indicated that soil organic matter is a key factor in maintaining high microbial enzyme activities and mitigating metal toxicity [53]. In general, microorganisms from serpentine soils showed a high level of tolerance to trace metals, such as Ni, Co, and Cr. An increase in the $\mathrm{Ni}$ concentration of the culture medium led to a significant decrease in bacterial densities of all soils. However, this decrease was less pronounced in the serpentine soils, indicating their adaptation to the toxic levels of $\mathrm{Ni}$ that they are normally exposed to [55]. Sometimes it may be difficult to attribute the observed effects on microbial communities to the heavy metal pollution due to their complex interactions in soil ecosystems $[8,30]$.

\section{Conclusions}

We can conclude that despite significant differences in $\mathrm{Ni}$ and $\mathrm{Cr}$ and some other heavy metal concentrations between serpentine and non-serpentine soils, only some microbial groups were significantly affected. In general, with the exception of ammonifiers, the results of regression analysis indicate the lack of significant effect of total and available $\mathrm{Ni}$ and $\mathrm{Cr}$ on microbial groups in soil with their high concentrations. This could be connected to previously noted developed tolerance of the microbial community to chronic high heavy metal concentrations. It appears that ammonifiers are the most sensitive microbial group to increased Ni concentrations and they can be perceived as sensitive indicators of its increase in soil ecosystems.

\section{Acknowledgements}

This research was supported by the Ministry of Education and Science and Technological Development of the Republic of Serbia, Project TR-37006 and Project SK-SRB-2013-0052, 451-03-545/2015-09/15. 


\section{References}

1. PANIKOV N.S. Understanding and prediction of soil microbial community dynamics under global change. Appl. Soil Ecol. 11 (2-3), 161, 1999.

2. LOMBARD N., PRESTAT E., VAN ELSAS J.D., SIMONET P. Soil specific limitations for access and analysis of soil microbial communities by metagenomics, FEMS Microbiol. Ecol. 78 (1), 31, 2011.

3. WUANA R.A., OKIEIMEN F.E. Heavy metals in contaminated soils: a review of sources, chemistry, risk and best available strategies for remediation, ISRN Ecol. Article ID 402647, 1, 2011.

4. LENART A., WOLNY-KOŁADKA K. The effect of heavy metal concentration and soil $\mathrm{pH}$ on the abundance of selected microbial groups within ArcelorMittal Poland steelworks in Cracow. Bull. Environ. Contam. Toxicol. 90 (1), 85, 2013.

5. GILLER K.E., WITTER E., MCGRATH S.P. Toxicity of heavy metals to microorganisms and microbial processes in agricultural soils: A review. Soil Biol. Biochem. 30 (10-11), 1389, 1998

6. OORTS K., GHESQUIERE U., SWINNEN K., SMOLDERS E. Soil properties affecting the toxicity of $\mathrm{CuCl}_{2}$ and $\mathrm{NiCl}_{2}$ for soil microbial processes in freshly spiked soils. Environ. Toxicol. Chem. 25 (3), 836, 2006.

7. PARELHO C., RODRIGUES A.S., BARRETO M.C., FERREIRA N.G.C., GARCIA P.V. Assessing microbial activities in metal contaminated agricultural volcanic soils an integrative approach. Ecotoxicol. Environ. Saf. 129, 242, 2016.

8. KIZILKAYA R., AŞKIN T., BAYRAKLI B., SAĞLAM M. Microbiological characteristics of soils contaminated with heavy metals. Eurasian J. Soil Sci. 40, 95, 2004.

9. RENELLA G., CHAUDRI A.M., FALLOON C.M., LANDI L., NANNIPIERI P., BROOKES P.C. Effects of Cd, Zn, or both on soil microbial biomass and activity in a clay loam soil. Biol. Fertil. Soils 43 (6), 751, 2007.

10. NIEMEYER J.C., LOLATA G.B., DE CARVALHO G.M., DA SILVA E.M., SOUSA J.P., NOGUEIRA M.A. Microbial indicators of soil health as tools for ecological risk assessment of a metal contaminated site in Brazil. Appl. Soil Ecol. 59, 96, 2012.

11. DENG L., ZENG G., FAN C., LU L., CHEN X., CHEN M., WU H., HE X., HE Y. Response of rhizosphere microbial community structure and diversity to heavy metal copollution in arable soil. Appl. Microbiol. Biotechnol. 99 (19), 8259, 2015.

12. SCHIPPER L, LEE W. Microbial biomass, respiration and diversity in ultramafic soils of West Dome, New Zealand. Plant Soil 262 (1), 151, 2004.

13. NIKLINSKA M., CHODAK M., LASKOWSKI R. Pollution-induced community tolerance of microorganisms from forest soil organic layers polluted with $\mathrm{Zn}$ or $\mathrm{Cu}$. Appl. Soil Ecol. 32, 265, 2006.

14. MRVIĆ V., ZDRAVKOVIĆ M., SIKIRIĆ B., ČAKMAK D., KOSTIĆ-KRAVLJANAC LJ. Harmful and dangerous elements in soils. In: Fertility and content of harmful and dangerous substances in the soils of central Serbia. Mrvić V., Antonović G., Martinović Lj., Eds., Monograph, Institute of Soil Science, Belgrade, Serbia, 75, 2009 [In Serbian].

15. SARIC Z. Practicum in microbiology. Belgrade, Serbia, Academic, 1989 [In Serbian]

16. GOVEDARICA M., JARAK M. Practicum in microbiology, $2^{\text {nd }}$ ed. Novi Sad, Serbia, Faculty of Agriculture, 1996 [In Serbian].
17. VOJINOVIC Z., RADULOVIC V., MODRIC A., STRUNJAK R., PRSA M., PETROVIC V., SARIC Z., TODOROVIC M. Microbiological testing of the soil profile. In Manual for the microbiological analysis of soils and waters, Tesic Z., Todorovic M. Eds., Belgrade, Yugoslavia: Yugoslav Society of Soil Science. 7, 1966.

18. SOLTANPOUR P.N., JOHNSON G.W., WORKMAN S.M, JONES JR. J.B., MILLER R.O. Inductively coupled plasma emission spectrometry and inductively coupled plasma mass spectrometry. In: Methods of Soil Analysis, Sparks D.L. Ed., Part 3. Madison, ASA and SSSA, 91, 1996.

19. BROOKS R.R. Serpentine and its vegetation: a multidisciplinary approach. Dioscorides, Portland, OR, 1987.

20. CEMPEL M., NIKEL G. Nickel: a review of its sources and environmental toxicology. Polish. J. Environ. Stud. 15 (3), 375, 2006

21. LI J., HU H.W., MA Y.B., WANG J.T., LIU Y.R., HE J.Z. Long-term nickel exposure altered the bacterial community composition but not diversity in two contrasting agricultural soils. Environ. Sci. Pollut. Res. Int. 22, 10496, 2015.

22. HARASIM P., FILIPEK T. Nickel in the environment. J. Elem. 20 (2), 525-534, 2015

23. OLIVEIRA H. Chromium as an Environmental Pollutant: Insights on Induced Plant Toxicity. J. Botany. Article ID 375843, 1, 2012.

24. PAL A., DUTTA S., MUKHERJEE P. K., PAUL A.K. Occurrence of heavy metal-resistance in microflora from serpentine soil of Andaman. J. Basic Microbiol. 45 (3), 207, 2005.

25. RINKLEBE J., ANTIĆ-MLADENOVIĆ S., FROHNE T., STÄRK H.-J., TOMIĆ Z., LIČINA V. Nickel in a serpentine-enriched Fluvisol: Redox affected dynamics and binding forms. Geoderma. 263, 203, 2016.

26. MANDIĆ L., ĐUKIĆ D., STEVOVIĆ V. Microbiological properties of Alumino-Siliceous soil under natural grasslands. Mikrobiologija. 39, 19, 2002.

27. OLIVEIRA A., PAMPULHA M.E. Effects of long-term heavy metal contamination on soil microbial characteristics. J. Biosci. Bioeng. 102 (3), 157, 2006.

28. LANKINEN P., KÄHKÖNEN M.A., RAJASÄRKKÄ J., VIRTA M., KATAKKAA. The effect of nickel contamination on the growth of litter- decomposing fungi, extracellular enzyme activities and toxicity in soil. Boreal Env. Res. 16, 229, 2011

29. KUCHARSKIJ., WYRWAA., BOROS E., WYSZKOWSKA J. Nitrification process as an indicator of soil contamination with heavy metals. Ecol. Chem. Eng. 16, 953, 2009.

30. MORAWSKA-PŁOSKONKA J., NIKLIŃSKA M. Effects of Soil Moisture and Nickel Contamination on Microbial Respiration Rates in Heavy Metal-Polluted Soils. Pol. J. Environ. Stud. 22 (5), 1411, 2013.

31. PESSOA-FILHO M., BARRETO C.C., DOS REIS JUNIOR F.B., FRAGOSO R.R., COSTA F.S., DE CARVALHO MENDES I., et al. Microbiological functioning, diversity, and structure of bacterial communities in ultramafic soils from a tropical savanna. A. Van. Leeuw. 107 (4), 935, 2015.

32. ELLIS R.J., MORGAN P., WEIGHTMAN A.J., FRY J.C. Cultivation-dependent and -independent approaches for determining bacterial diversity in heavy-metal contaminated soil. Appl. Environ. Microbiol. 69, 3223, 2003.

33. ANSARI M.I., MALIK A. Seasonal variation of different microorganisms with nickel and cadmium in the industrial wastewater and agricultural soils. Environ. Monit. Assess. $167(1-4), 151,2010$.

34. WYSZKOWSKA J., WYSZKOWSKI M. Influence of nickel and magnesium on the multiplication of microorganisms in 
the soil under cultivation of yellow lupine. Rocz. Glebozn. B, 73, 2003 [In Polish].

35. ALVAREZ A., SAEZ J.M., DAVILA COSTA J.S., COLIN V.L., FUENTES M.S., CUOZZO S.A., BENIMELI C.S., POLTI M.A., AMOROSO M.J. Actinobacteria: Current research and perspectives for bioremediation of pesticides and heavy metals. Chemosphere. 166, 41, 2017.

36. GROVER M., BODHANKAR S., MAHESWARI M., SRINIVASARAO C.H. Actinomycetes as mitigators of climate change and abiotic stress. In Plant Growth Promoting Actinobacteria, Subramaniam G., Arumugam S., Rajendran V. Eds., Springer Singapore, Singapore, 203, 2016.

37. FLOREA A.M., BUSSELBERG D. Occurrence, use and potential toxic effects of metals and metal compounds. Bio. Metals. 19 (4), 419, 2006.

38. WYSZKOWSKA J., BOROS E., KUCHARSKI J. Effect of interactions between nickel and other heavy metals on the soil microbiological properties. Plant Soil Environ. 53 (12), 544, 2007.

39. ZABOROWSKA M., WYSZKOWSKA J., KUCHARSKI J. Microbial activity in zinc contaminated soil of different $\mathrm{pH}$. Pol. J. Environ. Stud. 15 (2a), 569, 2006.

40. LAUBER C.L., HAMADY M., KNIGHT R., FIERER N. Pyrosequencing-based assessment of soil $\mathrm{pH}$ as a predictor of soil bacterial community structure at the continental scale. Appl. Environ. Microbiol. 75 (15), 5111, 2009.

41. ZHALNINA K., DIAS R., DE QUADROS P.D., DAVISRICHARDSON A., CAMARGO F.A., CLARK I.M., MCGRATH S.P., HIRSCH P.R., TRIPLETT E.W. Soil pH determines microbial diversity and composition in the park grass experiment. Microb Ecol. 69 (2), 395, 2015.

42. KANDZIORA-CIUPA M., CIEPAE R., NADGÓRSKASOCHA A. Assessment of Heavy Metals Contamination and Enzymatic Activity in Pine Forest Soils under Different Levels of Anthropogenic Stress. Pol. J. Environ. Stud. 25 (3), 1045, 2016.

43. ÜNVER I., MADENOGLU S., DILSIZ A., NAMLI A. Influence of rainfall and temperature on DTPA extractable nickel content of serpentine soils in Turkey. Geoderma. 202-203, 203, 2013.

44. MASSAS I., KALIVAS D., EHALIOTIS C., GASPARATOS D. Total and available heavy metal concentrations in soils of the Thriassio plain (Greece) and assessment of soil pollution indexes. Environ. Monitor. Asses. 185 (8), 6751, 2013.

45. IYAKA Y.A. Nickel in soils: a review of its distribution and impacts. Sci. Res. Essays. 6 (33), 6774, 2011.

46. ANTIBACHI D., KELEPERTZIS E., KELEPERTSIS A. Heavy Metals in Agricultural Soils of the MourikiThiva Area (Central Greece) and Environmental Impact Implications. Soil Sediment Contam. 21 (4), 434, 2012.

47. BINI C., MALECI L., WAHSHA M. Potentially toxic elements in serpentine soils and plants from Tuscany (Central Italy). A proxy for soil remediation. Catena. 148, 60, 2017.

48. WANG Y.P., SHI J.Y., LIN Q., CHEN X.C., CHEN Y.X. Heavy metal availability and impact on activity of soil microorganisms along a $\mathrm{Cu} / \mathrm{Zn}$ contamination gradient. J Environ Sci (China). 19, 848, 2007.

49. SHI Z., CAO Z., QIN D., ZHU W., WANG Q., ET A.L. Correlation models between environmental factors and bacterial resistance to antimony and copper. PLoS ONE. 8, 10, 2013.

50. ZHAO S., QIU S., CAO C., ZHENG C., ZHOU W., HE P. Responses of soil properties, microbial community and crop yields to various rates of nitrogen fertilization in a wheat-maize cropping system in north-central China. Agric. Ecosyst. Environ. 194, 29, 2014.

51. DEGENS B.P., SCHIPPER L.A., SPARLING G.P., VOJVODIC-VUKOVIC M. Decreases in organic C reserves in soils can reduce the catabolic diversity of soil microbial communities. Soil Biol. Biochem. 32 (2), 189, 2000.

52. LEJON D.P.H., PASCAULT N., RANJARD L. Differential copper impact on density, diversity and resistance of adapted culturable bacterial populations according to soil organic status. Eur. J. Soil. Biol. 46 (2), 168, 2010.

53. BOTEVA S., RADEVA G., TRAYKOV I., KENAROVA A. Effects of long-term radionuclide and heavy metal contamination on the activity of microbial communities, inhabiting uranium mining impacted soils. Environ. Sci. Pollut. Res. 23 (6), 5644, 2016.

54. AZARBAD H., VAN GESTEL C.A.M., NIKLIŃSKA M., LASKOWSKI R., RÖLING W.F.M., VAN STRAALEN N.M. Resilience of Soil Microbial Communities to Metals and Additional Stressors: DNA-Based Approaches for Assessing "Stress-on-Stress" Responses. Int. J. Mol. Sci. 17 (6), 933, 2016.

55. ÁLVAREZ-LÓPEZ V., PRIETO-FERNÁNDEZ Á., BECERRA-CASTRO C., MONTERROSO C., KIDD P.S. Rhizobacterial communities associated with the flora of three serpentine outcrops of the Iberian Peninsula. Plant Soil. 403 (1-2), 233, 2016. 